\title{
Představy budoucích pedagogů o hodnotách výchovy a vzdělávání
}

\section{The notion of educational values in the pedagogical thinking of pre-service educators}

\author{
Petr Bauman
}

\begin{abstract}
Abstrakt: Obsahem př́spěvku je prezentace dílčích výsledků výzkumu na téma „Představy budoucích pedagogů o cílech smyslu a hodnotách výchovy a vzdělávání“. Výzkum byl realizován formou dotazníkového šetření $(\mathrm{n}=554)$ mezi studenty JU v Českých Budějovicích. Použita byla technika pojmových asociací, otevřené otázky a technika nedokončených vět). Z hlediska představ budoucích pedagogů o hodnotách výchovy a vzdělávání byla zjištěna dominance individuálně-pragmatické orientace doprovázená důrazem na obsah vzdělávání (osvojení si znalostí a dovedností). Výpovědi respondentů byly napřič sledovanými skupinami poměrně homogenní.
\end{abstract}

Klíčová slova: hodnoty, pedagogické myšlení, kurikulum, ideová dimenze kurikula, znalosti o cílech, smyslu a hodnotách vzdělávání

\begin{abstract}
The paper presents a part of research findings into pre-service teacher's thinking about the ends, purposes and values of education. The research was designed as a survey among students at the University of South Bohemia $(n=554)$ using several questioning techniques: concept associations, open-ended questions, and unfinished sentences. Concerning the notion of educational values, individual-pragmatic orientation prevailed pointing out the content of education (acquiring knowledge and skills). Respondents' answers compared across various groups were relatively homogenous.
\end{abstract}

Keywords: values, teacher's thinking, curriculum, ideological dimension of curriculum, knowledge of educational ends, purposes and values

\section{Východiska, cíle výzkumu a výzkumné otázky}

Obecně se má za to, že klíčovým faktorem úspěšnosti či neúspěšnosti kurikulární reformy je sám učitel, přičemž - platí-li, že pro organizaci edukačního procesu či volbu vzdělávacích obsahů a vyučovacích metod je určující ideová dimenze kurikula (srov. Maňák, Janík, Švec, 2008, s. 23) - pak důležitost role učitele spatřjeme právě v pochopení a reflexi cílů, smyslu a hodnot vzdělávání a $\mathrm{v}$ jejich dalším zprostředkování $\mathrm{v}$ rámci edukačního procesu. ${ }^{1}$ Vzhledem k naší profesi vysokoškolského pedagoga vzdělávajícího budoucí vychovatele a učitele je pak v centru našeho zájmu otázka, jakým způsobem (pokud vůbec) lze znalosti o cílech, smyslu a hodnotách vzdělávání zprostředkovávat a kultivovat. Cílem našeho výzkumu² je tedy zjistit:

\footnotetext{
${ }^{1} \mathrm{~V}$ tomto bodu vycházíme z propojení teorie kurikula se Shulmanovým konceptem pedagogických znalostí, konkrétně znalostí o cílech, smyslu a hodnotách vzdělávání (knowledge of educational ends, purposes and values, srov. např. Janík 2004, 2005 aj.).

${ }^{2} \mathrm{~V}$ této stati představujeme pouze vybrané výsledky (a související cíle a postup řešení) výzkumu, a to pouze ve vztahu k problematice pojetí hodnot výchovy a vzdělávání.
} 
1. Jaké jsou představy budoucích pedagogů (studentů učitelství a vychovatelství na Jihočeské univerzitě v Českých Budějovicích) o hodnotách výchovy a vzdělávání?

2. Liší se tyto představy dle pohlaví, věku studentů a vybraných charakteristik jejich rodinného zázemí (praktická nebo intelektuální orientace rodiny, postoj rodiny k náboženství, dosažené vzdělání rodičů)?

3. Jsou tyto představy oborově specifické?

4. Liší se tyto představy u studentů vyšších a nižších ročníků?

5. Jak se do výpovědí respondentů promítnou různé způsoby dotazování?

Ačkoli empirický výzkum ideové dimenze kurikula není - např. ve srovnání s výzkumem obsahové dimenze - tolik tematizován, v posledních letech se této problematice věnuje stále více autorů. V České republice jsou to zejm. Janík (2005, 2007), Faberová et al. (2008), Skutil a Maněnová (2008), v poslední době pak výzkumný tým projektu Kvalitní škola (Píšová, Kostková, \& Janík, 2011). V zahraničí se výzkumu ideové dimenze kurikula v pedagogickém myšlení učitelů aktuálně věnuje nap̌r. Schiro (2008).

\section{Postup řešení a použité metody}

Vzhledem $\mathrm{k}$ tomu, že jsme nechtěli pouze ověřovat platnost námi formulovaných předpokladů či hypotéz, zkoumání výše uvedených otázek jsme se rozhodli provést formou kvalitativního výzkumu. Jelikož povaha výzkumných otázek předpokládala srovnávání získaných výpovědí od většího množství respondentů rozčleněných do několika skupin, zvolili jsme vzhledem k časovým, finančním a technickým možnostem realizaci výzkumu formou dotazníkového šetření, přičemž jsme využili tyto techniky:

1. Pojmové asociace k výrazu hodnoty, na kterých by měla výchova a vzdělávání „stavět".

2. Otevřená otázka: $V$ čem spočivá hodnota výchovy a vzdělávání na úrovni ZŠ?

3. Nedokončené věty: Škola se má starat především o to, aby...; Pro život je nejdůležitější, aby si žáci s sebou odnesli... ${ }^{3}$

Administrace dotazníků proběhla $\mathrm{v}$ průběhu října 2009 v rámci seminářů a přednášek na Teologické a Pedagogické fakultě JU v Českých Budějovicích (dostupný výběr). Celkem bylo získáno 554 vyplněných dotazníků se všemi údaji nezbytnými k analýze (407 studentů Pedagogické fakulty, 118 studentů Teologické fakulty a 29 studentů Filozofické fakulty; 461 Žen a 93 mužů; 455 respondentů ve věku 19-25 let, 99 respondentů ve věku 26-50 let).

\section{Prezentace a analýza dat}

\subsection{Použitý kategoriální systém}

Jelikož jsme pracovali s daty kvalitativní povahy, sledované kategorie jsme nestanovili předem, ale až na základě analýzy výzkumného materiálu. V první fázi jsme prováděli segmentaci odpovědí respondentů dle významových celků, poté jsme jednotlivé segmenty (výpovědi) kódovali. Takto jsme na konci první fáze, seskupováním jednotlivých výpovědí dle synonymity jejich významu, dospěli k celkem 91 výchozím konceptům, které jsme následně v pěti cyklech shlukové analýzy (hierarchické shlukování pro vážený průměr skupin dvojic) sloučili do těchto indukovaných kategorií:

- IK0: bez odpovědi (pomocná kategorie shrnující chybějící odpovědi);

\footnotetext{
${ }^{3}$ Znění těchto vět jsme za účelem možného srovnání výsledků převzali z širšího výzkumu pedagogických znalostí, který provedl Janík (2005).
} 
- IK1: personalistická orientace (důraz na osobnost jedince, rozvoj schopností a naplňování potřeb žáka bez důrazu na utilitárnost či praktickou využitelnost osobnostních dispozic; jednotlivec je cílem „o sobě“, resp. jiné prŕípadné cíle, jimž by mohl sloužit, jsou zamlčeny);

- IK2: individuálně-pragmatická orientace (těžištěm je jednotlivec, nikoli však už jako osobnost, která je cílem sama o sobě; důraz na praktickou využitelnost osvojeného, individuální výsledky, úspěch a sebeprosazení);

- IK3: sociálně-pragmatická orientace (sociální perspektiva a důraz na fungování společnosti; jednotlivec je uvažován primárně jako součást společnosti; důraz na konformní postoje, na začlenění do společnosti a přijetí sociálních norem).

- IK4: sociálně-etická orientace (důraz na sociální rozměr, nicméně základním principem zde není fungování společnosti, ale hledisko etické, tj. kategorie morálního a nemorálního, dobrého a zlého, výpovědi explicitně nevyjadřují utilitární aspekty sociálního „fungování“, ale spíše zůstávají na rovině sociálního „bytí‘);

- IK5: idealistická orientace (výpovědi, které koncepty individuálního či sociálního určitým způsobem přesahují nebo od nich abstrahují; důraz je kladen na obecné principy či ideje: ideály, vize, poslání, smysl života, štěstí, spravedlnost apod.);

- IK6: orientace na obsah vzdělávání (koncepty dotýkající se otázek Čemu vyučovat?, Co si osvojit?, které vzhledem $\mathrm{k}$ jejich formulaci nebylo možné jednoznačně přiřadit k žádné z výše uvedených kategorií: napřr. vědomosti, znalosti, dovednosti, návyky, postoje, informace, poznatky, poznání, přehled apod.);

- IK7: organizačně-metodická orientace (koncepty vyjadřující organizační, metodickou, materiální, sociální či jinou determinovanost edukačních procesů).

\subsection{Nálezy}

Jak ukazují obrázky 1 až 3, ze sedmi identifikovaných kategorií je nejčetněji zastoupena kategorie IK6 (orientace na obsah vzdělávání), naopak IK5 (idealistická orientace) je kategorií s celkově nejnižší četností zastoupení. Tyto výsledky jsou navíc poměrně homogenní např́íč všemi sledovanými skupinami. Statisticky významné rozdíly $\left(\chi^{2}, p=0,05\right)$ byly zjištěny pouze u četnosti zastoupení IK5, a to mezi studenty pedagogické a teologické fakulty (významně četnější u TF). Další výrazný rozdíl (za statisticky významný by mohl být považován na hladině významnosti $\mathrm{p}=0,052$ ) byl zaznamenán mezi studenty pedagogických učitelských a pedagogických neučitelských oborů (četnější zastoupení IK5 bylo zaznamenáno zejm. u studentů vychovatelství, obor pedagogika volného času). Statisticky významné rozdíly $\left(\chi^{2}, p=0,05\right)$ naopak nebyly zjištěny mezi muži a ženami, mladšími a staršími respondenty, studenty nižších a vyšších ročníků ani studenty s různým rodinným zázemím (praktická nebo intelektuální orientace, postoj k náboženství, vzdělání rodičů). 


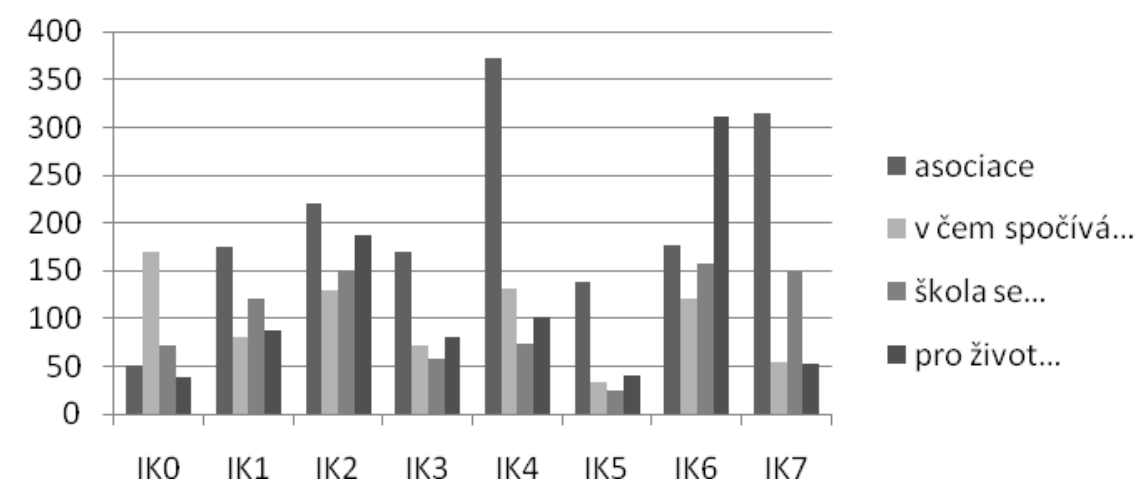

Obrázek 1. Zastoupení jednotlivých kategorií dle způsobu dotazování, absolutní četnosti.

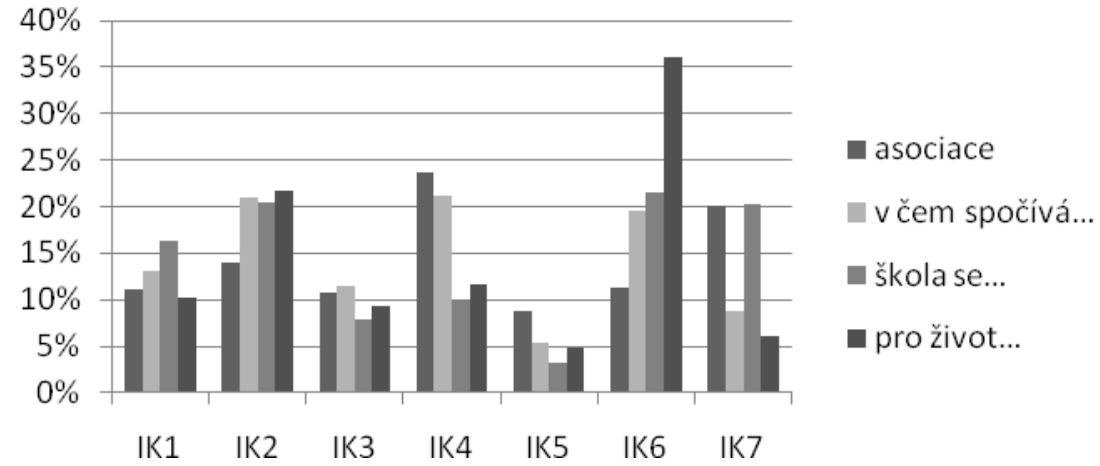

Obrázek 2. Zastoupení jednotlivých kategorií dle způsobu dotazování, relativní četnosti dle celkového počtu výpovědí pro daný způsob dotazování.

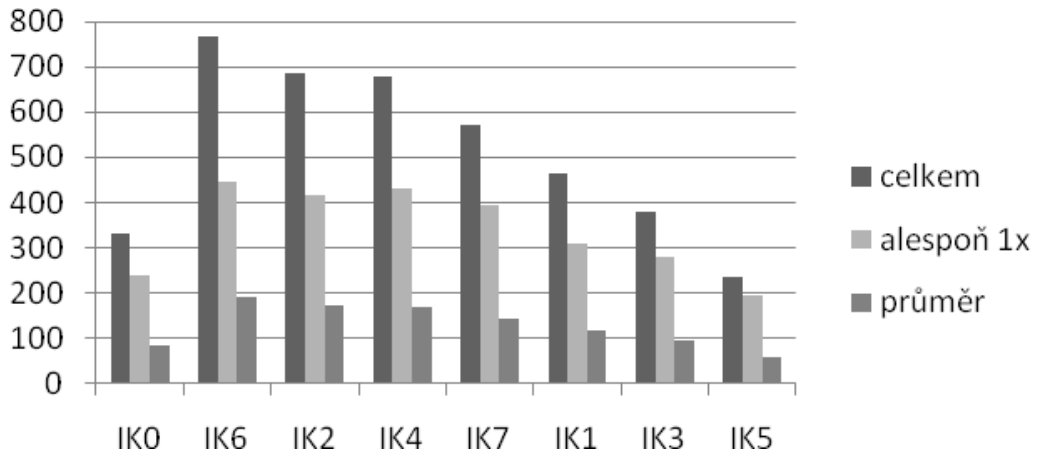

Obrázek 3. Zastoupení jednotlivých kategorií: celkové četnosti; počet respondentů, jejichž výpovědi alespoň v jednom ze čtyř př́padů (dle způsobu dotazování) byly zařazeny do dané kategorie; aritmetický průměr absolutních četností pro jednotlivé způsoby dotazování.

Současně se ukazuje, že výpovědi respondentů byly jednotlivými způsoby dotazování významně ovlivněny, a to zejména v př́padě kategorií IK6 (orientace na obsah vzdělávání se prosadila zejm. díky formulaci nedokončené věty Pro život je nejdilležitějšś, aby si žáci s sebou odnesli..., naopak v prŕípadě pojmových asociací patřila mezi kategorie s průměrnou četností zastoupení) a IK7 (organizačně-metodická orientace byla četně zastoupena v pojmových 
asociacích a v dokončení věty Škola se má starat především o to, aby..., naopak v ostatních dvou případech se v takové míře neprosadila. Jako pro respondenty nejobtížnější se jeví otevřená otázka $V$ čem spočivá hodnota výchovy a vzdělávání na úrovni $Z S ̌$ ? (v tomto př́padě byla zaznamenána významně nejvyšši četnost vynechaných odpovědí). Naopak kategoriemi s nejnižším rozptylem, tj. nejméně podléhajícími odlišným způsobům dotazování, byly IK3 (sociálně-pragmatická orientace), IK5 (idealistická orientace) a IK1 (personalistická orientace).

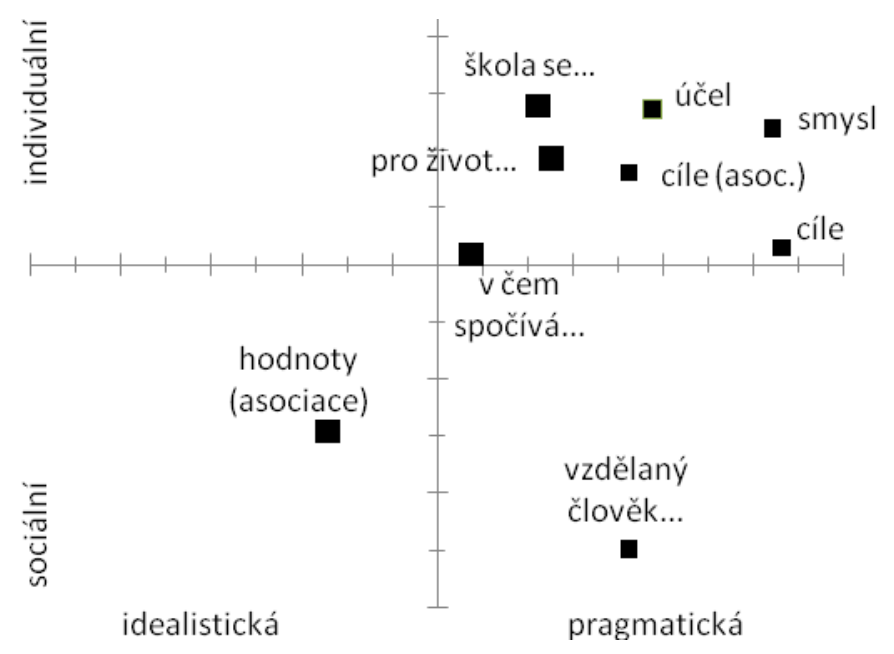

Obrázek 4. Individuální-sociální, pragmatická-idealistická dimenze.

Srovnáme-li výpovědi v dimenzích individuální (IK1+IK2) - sociální (IK3+IK4) a pragmatická (IK2+IK3) - idealistická (IK4+IK5), jak ukazuje obrázek 4, celkově převládá orientace individuálně-pragmatická. ${ }^{4} \mathrm{Za}$ povšimnutí stojí rovněž tendence $\mathrm{k}$ přesunu od důrazu na obecné ideje (smysl života, hodnoty apod.) a sociální aspekty („lepší společnost“") k orientaci individuálně-pragmatické (sebeprosazení, úspěch, „aby mu to k něčemu bylo“), tj. při nižším počtu výpovědí (pokud studenti své odpovědi zužují, srov. pojmové asociace a odpovědi na otevřenou otázku), nejdř́íve „odpadají“ aspekty idealistické a sociální.

\subsection{Závěry a diskuse}

Ačkoli, vzhledem k povaze výzkumného vzorku, nemůžeme formulovat příliš obecné závěry o povaze pojetí hodnot výchovy a vzdělávání u budoucích pedagogů, v prípadě studentů Jihočeské univerzity zahrnutých do výzkumného vzorku se ukazuje, že napríič velmi rozmanitými skupinami respondentů převládá důraz na aspekty obsahu vzdělávání a aspekty individuálně-pragmatické (hodnota výchovy a vzdělávání je spatřována v tom, „,co se naučím“ a ,že mi to k něčemu bude“), zcela upozaděny jsou aspekty ideálů (demokracie, rozvoj

\footnotetext{
${ }^{4}$ Jednotky na ose představují 50 výpovědí. Výsledná hodnota pro umístění na př́slušné ose byla vypočtena jako rozdíl četností relevantních kategorií, např. dimenze idealistická-pragmatická pro výpovědi asociované $\mathrm{k}$ výrazu hodnoty, na kterých by měla výchova a vzdèlávání ,stavět “ $($ IK2+IK3 $)-($ IK4+IK5) $=(220+169)-(372+138)=$ -121. Pro srovnání byly do obrázku zařazeny rovněž hodnoty, které byly předmětem výzkumu, nicméně v této stati nebyly prezentovány (asociace $\mathrm{k}$ výrazu cile výchovy a vzdělávání, odpovědi na otevřené otázky Co je cílem/smyslem/účelem výchovy a vzděláváni na úrovni základni školy? a výpovědi vážící se $\mathrm{k}$ nedokončené větě Vzdèlaný člověk se pozná podle toho, že...).
} 
kultury, směřování „k něčemu vyššímu“ apod.) či vědění bez pragmatických či utilitárních důrazů (,„pro krásu poznání“), a to u studentů učitelství ještě výrazněji než u studentů oborů pedagogických neučitelských.

Vysoká homogenita výpovědí napříč sledovanými skupinami (oproti očekávání také ve srovnání mužů i žen či mladších a starších respondentů) spolu s velkou nestabilitou výpovědí jednotlivých respondentů při různých způsobech dotazování nás však vede k opatrnosti při interpretaci těchto výsledků (jedná se o ustálené pojetí hodnot výchovy a vzdělávání, nebo spíše o nahodilé odpovědi více či méně evokované zadáním?). Zároveň před nás staví výzvu hledat a dále ověřovat spolehlivější způsoby poznávání tohoto typu pedagogických znalostí.

\section{Literatura}

Faberová, M., et al. (2008). Výzkum implementace základnich cílů vzdělávání (tzv. 4 piliřre) v primárním vzdělávání ve školách ČR. Hradec Králové: $\mathrm{M} \& \mathrm{~V}$.

Janík, T. (2004). Význam Shulmanovy teorie pedagogických znalostí pro oborové didaktiky a pro vzdělávání učitelů. Pedagogika, 54(3), 243-250.

Janík, T. (2005). Znalost jako kličcová kategorie učitelského vzdělávání. Brno: Paido.

Janík, T. (2007). Cílová orientace ve výuce fyziky: exkurz do subjektivních teorií učitelů. Pedagogická orientace, 17(1), 12-33.

Maňák, J., Janík, T., \& Švec, V. (2008). Kurikulum v současné škole. Brno: Paido.

Píšová, M., Kostková, K., \& Janík, T. (Eds.). (2011). Kurikulární reforma na gymnáziích: prípadové studie tvorby kurikula. Praha: VÚP v Praze.

Schiro, M. S. (2008). Curriculum theory: Conflicting visions and enduring concerns. Thousand Oaks: Sage.

Skutil, M., \& Maněnová, M. (2008). Implementace základních cílů vzdělávání do školních vzdělávacích programů: vybrané výsledky výzkumu. In T. Svatoš \& J. Doležalová (Eds.), Pedagogický výzkum jako podpora proměny současné školy. Sborník z XVI. konference ČAPV (pp. 205-211). Hradec Králové: Gaudeamus.

\section{Kontakt}

PaedDr. Petr Bauman

Jihočeská univerzita v Českých Budějovicích

Teologická fakulta, Katedra pedagogiky

Kněžská 8, 37001 České Budějovice

e-mail: bauman@tf.jcu.cz

\section{Bibliografické údaje}

Bauman, P. (2011). Představy budoucích pedagogů o hodnotách výchovy a vzdělávání. In T. Janík, P. Knecht, \& S. Šebestová (Eds.), Smíšený design v pedagogickém výzkumu: Sborník př́spěvků z 19. výročni konference České asociace pedagogického výzkumu (s. 298-303). Brno: Masarykova univerzita. ISBN 978-80-210-5774-6.

Dostupné z: http://www.ped.muni.cz/capv2011/sbornikprispevku/bauman.pdf doi: 10.5817/PdF.P210-CAPV-2012-1 